The Characteristics of Jangkar Kelud Radio as Disaster Community Radio

\title{
Karakteristik Radio Jangkar Kelud sebagai Radio Komunitas Kebencanaan
}

\section{Anam Miftakhul Huda ${ }^{1}$, Atwar Bajari ${ }^{2}$, Asep Saeful Muhtadi ${ }^{3}$, Dadang Rahmat ${ }^{2}$}

${ }^{1}$ Study Program of Communication Science, Universitas Islam Balitar, Jl. Majapahit No. 2-4, Blitar 66137, Indonesia

${ }^{2}$ Faculty of Communication Sciences, Universitas Padjadjaran, Jl. Raya Bandung Sumedang KM 21, Jatinangor 45363, Indonesia

${ }^{3}$ Faculty of Communication Sciences, Universitas Islam Bandung, Jl. Tamansari No. 1, Bandung 40116, Indonesia

*Corresponding author, e-mail: anamramadhan@gmail.com

\begin{abstract}
This study aims to find out the characteristics of Jangkar Kelud Radio as disaster community radio. The existence of community radio is as information means of disaster mitigation. There are nine Jangkar Kelud community radio stations spread in three regencies of Malang, Blitar, and Kediri. The object of this research is Jangkar Kelud community radio. The method of this research is descriptive qualitative that is the characteristic of Jangkar Kelud Radio is as disaster community radio. The results of this study show the characteristics of community radio is in line with Law No. 32 year 2002. The distinctiveness of Jangkar Kelud community radio are the presence of the radio geographically is in the prone disaster area, the content of on-air and off-air programs is about disaster mitigation, the concept of community radio is by, from and for visible disaster risk reduction through the radio management participation.
\end{abstract}

Keywords: Characteristics, Jangkar Kelud Radio, Community Radio, Disaster.

\begin{abstract}
Abstrak
Penelitian ini bertujuan untuk mengetahui karakteristik Radio Jangkar Kelud sebagai radio komunitas kebencanaan. Keberadaan radio komunitas sebagai sarana informasi mitigasi bencana. Jumlah radio komunitas Jangkar Kelud ada sembilan radio yang tersebar di tiga Kabupaten: Malang, Blitar, dan Kediri. Obyek penelitian ini adalah radio komunitas Jangkar Kelud. Metode penelitian ini secara deskriptif kualitatif yakni melihat karakteristik radio Jangkar Kelud sebagai radio komunitas kebencanaan. Hasil penelitian ini menunjukan karakteristik radio komunitas sesuai UU No. 32 tahun 2002. Kekhasan radio komunitas Jangkar Kelud berada secara geografis di kawasan rawan bencana. Isi program secara on air maupun off air tentang mitigasi bencana, konsep radio komunitas oleh, dari dan untuk melihat pengurangan resiko bencana melalui partisipasi pengelolaan radio.
\end{abstract}

Kata Kunci: Karakteristik, Radio Jangkar Kelud, Radio Komunitas, Kebencanaan.

\section{Copyright (C) 2018 Universitas Semarang. All rights reserved.}

\section{Introduction}

Community is a social group of some organisms that share environment, generally have the same interests and habitats. In the human community, the individuals in it can have purpose, trust, resources, preferences, needs, risks and a number of other similar conditions (Wenger, McDermott \& Snyder, 2002). Community comes from the term community which means all people living in a certain place, as well as a group of people with the same intention or interest (Sudibyo, 2004). Community broadcasting

Article History: Received January 26, 2018; Revised July 25, 2018; Accepted July 27, 2018; Published July 31, 2018 
institution (LPK) is one of a broadcasting institution in the form of Indonesian legal entity, established by a certain community, independent, and non-commercial, with lowpower, also to serve the interests of the community.

Referring to the above community understanding, this research is about the existence of disaster community located on the slopes of Mount Kelud, social activities formed by the community in Lingkar Kelud for reducing Mount Kelud disaster risk. The community incorporated in the slopes of Mount Kelud is a kind of public awareness on the dangers faced. To reduce disaster risk, Jangkar Kelud community has community media. This community media is to socialize the disaster and to establish intimacy among members, this is supported by the lattest technology.

Meanwhile, according to Merton (McQuail, 2012), Functionalist Theory explains that social practice and institution are related to human needs. Society is seen as a system that deals with life, so anything related to human beings can be judged by the function or the benefit of its existence. Media can be seen as part of the system (McQuail, 2012). The existence of media is part of the community system. The description of community life is directly or indirectly related to the existence of the media. While the media itself comes from the human mind to develop that aims effectively in communicating.

The role of Jangkar Kelud community media basically is almost the same role with the mass media in general, only on the area (level of playing field) is limited. Community media outreach in Law limits the space for community media.

Community television and radio stations are included in community broadcasting institutions. According to Law No. 32 year 2002, 'Lembaga Penyiaran Komunitas' (The Community Broadcasting Institutions) is broadcasting institution in the form of Indonesian legal entity, established by certain communities, independent, and noncommercial, with low transmit power, limited coverage area, and to serve the interests of the community.

In forming a community, a concept of community design and maintenance is very important so that the community can become Jangkar Kelud community that cares about the Kelud disaster. The importance of the existence of community radio as a means of disaster risk reduction of Mount Kelud is one of the media for disaster mitigation.

Radio can be used as disaster mitigation program, especially in disaster prone areas. With the program, the community is invited to have sensibility and quick reaction to the natural phenomena and the marker of disaster. This is an anticipation of reducing disaster risks either for personal safety or their families.

Promono and Wibowo's Research (2013) is about the existence of Merapi community radio. Independence of Merapi community radio in disaster prone area of Mount Merapi is the desire of the people of Deles hamlet to communicate with local people. The independence of citizens to live the radio needs is purely based on the surrounding society support for the existence of the radio community.

Based on pre-research observation, Jangkar Kelud association has a means of communication in the form of community radio. Jangkar Kelud community radio broadcasts through channel 107.8 which is used by nine community radios where each has its own specificities in the broadcast and format program.

The existence of Jangkar Kelud Radio in Disaster Prone Areas I Kediri Regency there are four community radio, namely: Kelud FM Radio in Margomulyo Hamlet, Sugihwaras Village, Ngancar Sub-district; Sempu Raya FM Radio located in Sempu 
Village, Ngancar Sub-district; RJKS FM Radio in Satak Village, Puncu Sub-district; and Ampel Denta Voice FM Radio located in Siman Village, Kepung Sub-district.

In Disaster Prone Areas I in Blitar Regency there are three community radio, namely: S2 FM Radio located in SosoVillage, Gandusari Sub-district; Lintas Kelud FM Radio in ModanganVillage, Nglegok Sub-district; and Candi Kelud FM Radio located in Candirejo Village, Ponggok Sub-district.

In Disaster Prone Areas I in Malang Regency there are two community radio, namely: Pandawa FM Radio in Pondok Agung Village, Kasembon Sub-district and Smart FM Radio in Ngantru Village, Ngantang Sub-district.

Based on the description above, this research describes the existence of Jangkar Kelud community radio through its characteristics. This mapping is to know the existence of community radio disaster that has an important role in disaster risk reduction more clearly.

\section{Methodology}

In this research, the type of research used is qualitative descriptive which uses interview result with informant as primary data obtained in the interview, observation result in the research location and the data about the informant.

Panutra and Atmojo examines community involvement in the management of Merapi FM Radio (Panutra \& Atmojo, 2012). Community radio is established and organized by the community to serve the interests of the community. The research conducted by Panutra and Atmojo emphasized how the management of the community radio in disaster prone areas. Likewise, Birowo (2013) conducted research on Lintas Merapi Community Radio, a community radio located in Deles, Sidorejo Village, Kemalang Sub-district, Klaten Regency. The results of the research show that media can develop because it is able to meet the needs of the community. Starting from the need for media for emergency situation caused by eruption of Mount Merapi, this media then is not only functioning as broadcasting media but also as a means of citizens to conduct activities. This radio can explain that the power of community radio is in its ability to combine on air and off air programs. In contrast to this research which more clarifize the existence of community radio in disaster prone areas both situationally and its function.

Data collection techniques used in this research are systematic field observation in social setting and in-depth interviews to obtain information accurately and considered to master the material of this research.

In determining an informant, the considerations are on: the accuracy and validity of the information obtained, the number of informants required based on the research objectives and the authority of a researcher in determining an informant who deserves to be interviewed.

\section{Result and Discussion}

Based on documentary data and interviews with community radio source, Jangkar Kelud exist since its inception from the founding of community organization called Jangkar Kelud, this organization is the citizen initiative of their unrest when Mount Kelud eruption occurred in 2007. In 2011 there was anxiety, Jangkar Kelud thought of the need for community media embeded by Jangkar Kelud community.

The existence of disaster community radio located in Lingkar Kelud is an early warning system, here community radio is not just technology. The emphasis of the 
existing communication chain in the community radio is part of Mount Kelud disaster risk reduction, the use of community radio is to provide the public awareness on the disaster to be faced. The action is the future investment effort for disaster risk reduction both for victims of death and material of the residents around Lingkar Kelud.

The existence of community radio is not just information technology but as an investment to the community to reduce disaster risk of Mount Kelud. This investment has big meaning, the existence of community radio is as social capital to get big profit. The advantage is the risk of disaster victims, with a lot of information about disaster preparedness in disaster-prone areas of Mount Kelud, the people are not panic anymore when there is disaster because they are ready to deal with it.

The people are panic when disaster struck because of the lack of information and insights about the disaster. If the community does not get or lack of information, it is likely to increase the number of casualties and the many risks it receives, so the more the information on the disaster risk reduction insights gained by the community the more minimum the risk of the disaster. Thus, the easier it is to obtain information tools such as radio or other media, the less risk it is because they have prepared themselves (risk reduction learning).

This is based on field observation of the existence of Jangkar Kelud community radio comes from the thought of citizen or Jangkar Kelud community that has established first. The establishment of Jangkar Kelud community has a sense of community togetherness in Lingkar Kelud with brotherhood mission. This brotherhood (togetherness) requires a medium to facilitate communication network as well as a vehicle for learning together and entertainment for the residents in Lingkar Kelud.

Jangkar Kelud Radio as Disaster Information Media

The use of community radio is a new communication tool and potential for succeeding rural-urban development and is a strategy to help people put communities in a better position in implementing development projects, leveraging their livelihoods and empowering citizens to improve their lives, giving basis to the community to discuss and talk about development strategies as well as local government to inform citizens about new programs in the local context (Hakam, 2011).

The existence of Jangkar Kelud community radio have strategic position as Mount Kelud disaster information media. The role of printed media as well as audio and audio visual in disaster risk communication has very vital role, but unfortunately there are various obstacles in its implementation. Commercial media is very limited with media policy to be profit oriented.

Therefore the role of community media that can accommodate the learning on disaster for citizen is delivered. This disaster community radio is as an alternative media for citizens to be able to learn disaster risk reduction. In addition Jangkar Kelud community radio is as early warning system in the area of Lingkar Kelud. The existence of media and the responsibility of press to be early warning system where the media perform its function as early warning system (Setyowati, 2011).

The community radio is one of Jangkar Kelud media to socialize awareness of Mount Kelud disaster in addition to other communication tools: handy talky, book or module, direct socialization, simulation and social media used by Jangkar Kelud community to reduce disaster risk and to establish residents of Lingkar Kelud brotherhood (paseduluran). 
Socialization should not be done when the volcano at the border of Kediri Regency, Blitar Regency and Malang Regency is critical, but it is more effective when Mount Kelud is in normal condition.

Jangkar Kelud community radio is very useful for the citizens, one of them is to inform the news of Mount Kelud status development. The type of Jangkar Kelud community radio information is delivered by the community through public service ads, appeals, and recording of Mount Kelud development.

This community radio broadcasting pattern has its own uniqueness based on observation and in-dept interview conducted by the researchers.

1. Broadcast with a simple tool of a set of computer and mixer, disaster community radio broadcasts from the surrounding Mount Kelud or in the lava flow of disasterprone areas of Mount Kelud.

2. Broadcasting with experience capital from previous disasters, community radio activist has very influential role from the establishment, management, until the evaluation of the running of this community radio to its existence now.

3. Broadcast with local language style, language style easily understood by the surrounding community, not with the standard language. Thus, the broadcast style contains entertainment and easy to understand, on the sidelines of the broadcast information on the development status of Mount Kelud with seismic code is inserted so without their awareness the community understand the activities of Mount Kelud.

Based on the field observation the people in the disaster prone areas of Mount Kelud highly appreciate the existence of this community radio. The existence of Jangkar Kelud community radio is reflected in the radio role itself in disaster mitigation. Chain of disaster mitigation started from pre-disaster with disaster awareness of the danger of disaster programs. When the crisis or disaster happen Jangkar Kelud community radio is ready to help the residents of Lingkar Kelud community evacuate themselves. After the disaster occurred the existence of this radio is still used by the community as reconstruction stage or disaster rehabilitation.

The community radio of Jangkar Kelud is as citizen media, community radio is very useful. At the time of Mount Kelud eruption in 2013, Jangkar Kelud community radio disseminate information about the weather condition, eruption activities, and others. Such information becomes the reference for the citizens to avoid the risk of hot lava disaster. For that, in the future, it is hoped that radio activists are able to develop information systems in a sustainable manner.

Jangkar Kelud disaster community radio has its own uniqueness, when described in the characteristics of community radio according to Law no. 32 year 2002 is included in the criteria.

\begin{tabular}{|c|c|c|}
\hline No & Elements & Characteristics \\
\hline 1 & $\begin{array}{c}\text { The Enforcement } \\
\text { Legal Entity }\end{array}$ & Jangkar Kelud community \\
\hline 2 & Ownership & Jangkar Kelud community association \\
\hline 3 & Demography & $\begin{array}{c}\text { In the disaster-prone or affected by the disaster location, } \\
\text { there are 9 radios in three regency. }\end{array}$ \\
\hline 4 & Nature & Independent and non-commercial \\
\hline 5 & Funding Sources & $\begin{array}{c}\text { Community member contribution, donation, grant, non- } \\
\text { binding sponsorship }\end{array}$ \\
\hline 6 & Broadcast Range & Maximum Radius 2,5 KM Air \\
\hline 7 & Effective Radiated & Maximum 50 Watt \\
\hline
\end{tabular}




\begin{tabular}{|c|c|c|}
\hline & Power (ERP) & \\
\hline 8 & Broadcast Content & from, by and for the Benefit of the Disaster Community \\
\hline 9 & Frequency Channels & $107,7 \mathrm{FM} ; 107,8 \mathrm{FM}$; and 107,9 FM \\
\hline
\end{tabular}

Table. 1

Typical Characteristics of Broadcasting Institution of Jangkar Kelud Community Radio (Source: Researchers, 2017)

\section{Conclusion}

Radio included in this category are Candi Kelud FM Radio, Blitar Regency; Lintas Kelud FM Radio, Blitar Regency; Soso FM Radio, Blitar Regency, Sera FM Radio, Kediri Regency; RJKS FM Radio, Kediri Regency; Pandowo FM Radio, Malang Regency and Smart FM Radio, Malang Regency. Radio located in hazard prone areas of Mount Kelud is as a means of disaster information media/disaster mitigation began from pre-disaster, and post-disaster eruption of Mount Kelud. Community radio management is done by Jangkar Kelud community participation in reducing the disaster risk.

\section{Acknowledgement}

Thanks to all parties who have helped the completion of this research, Promoter Team from Universitas Padjadjaran, informants from the Jangkar Kelud community and BPPDN Dikti Scholarship that finances the completion of this research.

\section{References}

Birowo, M. A. (2013). Pemanfaatan Radio Komunitas dan Jaringan Sosial dalam Respon Bencana Gunung Merapi: Studi Kasus Radio Komunitas Lintas Merapi, Deles, Klaten, Jawa Tengah. http://e-journal.uajy.ac.id/1227/

Hakam, U. (2011). Konvergensi Media dalam Radio Komunitas. Jurnal Penelitian IPTEK-KOM, 13(1), June 2011.

McQuail, D. (2012). Teori-Teori Komunikasi Massa. Jakarta: Erlangga.

Panutra, E., \& Atmojo, P. W. (2012). Radio Komunitas Merapi FM: Studi Tentang Keterlibatan Komunitas dalam Pengelolaan Radio Merapi FM. Transformation 4(22): 1-8. Retrieved from http://download.portalgaruda.org/article.php?article=114780\&val=5263.

UU No. 32. (2002). Penyiaran.

Setyowati, R. M. (2011). Wikileaks dan Agenda Setting Media. Jurnal The Messenger 2(2): $28-32$.

Sudibyo, A. (2004). Ekonomi Politik Media Penyiaran. Jakarta: ISAI - LKIS

Wenger, E., McDermott, R., \& Snyder, W. M. (2002). Communities of Practice and Their Value to Organizations. Cultivating Communities of Practice: a Guide to Managing Knowledge: 1-22. 